\title{
Morphometric analysis to prioritize sub-watershed for flood risk assessment in Central Karakoram National Park using GIS / RS approach
}

\author{
N. Hassan. Syed ${ }^{\text {ab* }}$, A. Adbul. Rehman ${ }^{\text {b }, ~ D . ~ H u s s a i n ~}{ }^{\text {a }}$, S. Ishaq ${ }^{\text {a }}$ A. Ahmed. Khan ${ }^{\text {a }}$ \\ ${ }^{a}$ Karakuram International University, Gilgit, Pakistan, - (syed.najam, dostdar.hussain, aftab.ahmed)@kiu.edu.pk \\ ${ }^{\mathrm{b}}$ Geo-Informatics and Real Estate, University of Technology, Malaysia
}

KEY WORDS: GIS / RS, Watershed, Morphometric parameters, Flush floods, Risk Assessment

\begin{abstract}
Morphometric analysis is vital for any watershed investigation and it is inevitable for flood risk assessment in sub-watershed basins. Present study undertaken to carry out critical evaluation and assessment of sub watershed morphological parameters for flood risk assessment of Central Karakorum National Park (CKNP), where Geographical information system and remote sensing (GIS \& RS) approach used for quantifying the parameter and mapping of sub watershed units. ASTER DEM used as a geo-spatial data for watershed delineation and stream network. Morphometric analysis carried out using spatial analyst tool of ArcGIS 10.2. The parameters included were bifurcation ratio $(\mathrm{Rb})$, Drainage Texture (Rt), Circulatory ratio (Rc), Elongated ratio (Re), Drainage density (Dd), Stream Length (Lu), Stream order (Su), Slope and Basin length (Lb) have calculated separately. The analysis revealed that the stream order varies from order 1 to 6 and the total numbers of stream segments of all orders were 52. Multi criteria analysis process used to calculate the risk factor. As an accomplished result, map of sub watershed prioritization developed using weighted standardized risk factor. These results helped to understand sensitivity of flush floods in different sub watersheds of the study area and leaded to better management of the mountainous regions in prospect of flush floods.
\end{abstract}

\section{INTRODUCTION}

Watershed means the area from where the runoff resulting due to rainfall flows, passes through a single point into large streams, lakes, rivers and oceans. A watershed is a naturally occurred hydrologic unit, which categorize by a common climatic, topographic and other physical condition surrounding it. Many terms have been used in order to prioritize the rank of watershed, like sub watershed, basin and sub basin (Javed, Ahmad et al, 2009). Sub-watershed prioritization mainly based on the analysis of morphometric parameters using GIS and remote sensing techniques (Sujata, Sudhakar, \& V R, 1999). Morphometric analysis is very imperative in any hydrological investigation and it is unavoidable for the management of drainage basins (Rakhna et al, 2011). Watershed management has vital consideration for conservation of underground and surface water.

Different parameters are important while making a watershed management development plan, like the erosional status, lithology, topography as well as the drainage pattern of the area (Pisal et al, 2013). The morphometric parameters help to identify and understand the physical features of catchment with respect to floods (Bhatt \& Ahmed, 2014).

Flooding is the most devastating natural hazard in Pakistan, where the floods have demonstrated severe-ness in the country during many occasions. Floods are common phenomenon throughout the country however; their characteristics differ from region to region. The mountainous region of GilgitBaltistan (GB) always affected due to flash floods.

Flash floods in August 2015 badly affect the region and as a result seven people killed and six injured. As many as 812 houses damaged in 286 villages affecting 136,000 people (The Express Tribune Blogs, 2016). Furthermore, it destroyed the roads which are main source of communication and water channels, which are the main source for drinking and irrigation in the region. National Disaster Management Authority (NDMA) recently also reported many of the flood incidents particularly in the Sikardu district of the region. Resulting of several casualties, damages to infrastructure and many of the landslides (FloodList, 2017)

In order to estimate the flood response, it is very important to understand morphometric parameters like, stream magnitude, drainage density and topography in flash flood prone regions (Waikar \& Nilawar, 2014). For this purpose, Remote Sensing (RS) and Geographic Information System (GIS) technology used to find the interrelation of morphometric parameters and further identify the area under varying flood conditions. RS \& GIS technology has been proven to be effective tool for the assessment of floods risk (Omran et al, 2011). Morphometric analysis and prioritization of watersheds are vital parameters for flood management and assessment (Youssef et al, 2011).

Thus, the aim of this study was to understand the hydrologic behaviour of flash flood prone drainage basin in CKNP region of GB by using GIS and RS technology. A potential flood hazard map is developed, which is based on geomorphic parameters. It gives the degree of risk of individual sub-basin in watershed, through combining the normalized values of parameters. The scientific information generated through current study will provide help for the decision makers \& stakeholders of the CKNP management plan to cope up with climate-induced hazards.

\subsection{Rationale of the study}

It is being observed that many of local communities and NGOs working for resource management are incorporating GIS technologies for management. This qualifies the needs of

\footnotetext{
*Corresponding Author: syed.najam@kiu.edu.pk
} 

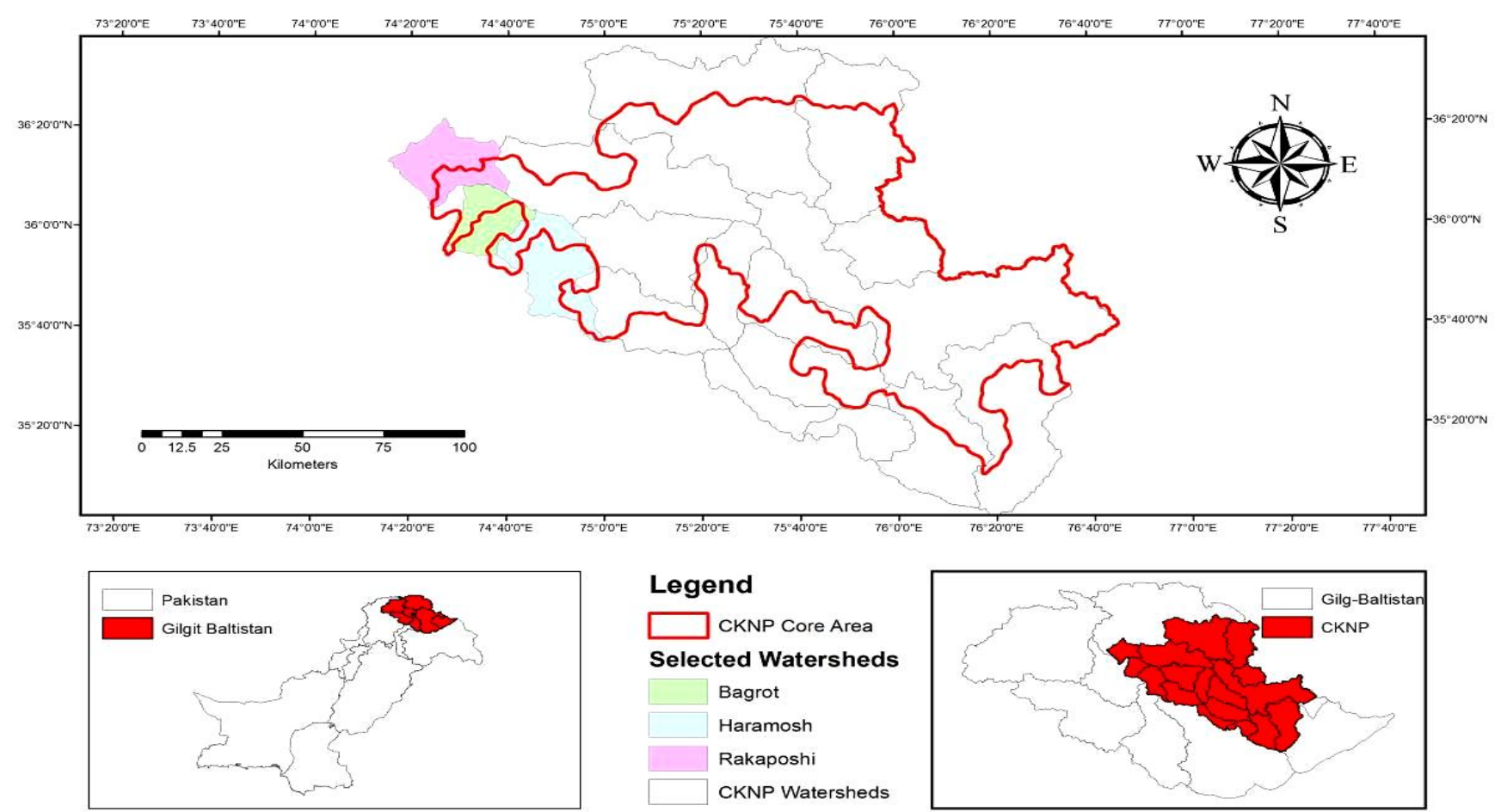

Figure 1: Central Karakoram National Park (Study Area)

geoscience technologies for CKNP (McCall, 2005). In natural resource management (NRM), watershed unit has significant importance. Prioritization of watershed is one of the approaches to understand NRM on said unit level, for which morphometric analysis is commonly used (Javed Khanday, \& Ahmad, 2009). Drainage basin and drainage networks consequently used to predict flash floods when these are quantitatively described (El-Behiry et al, 2006). Morphometric analysis is quantification of different morphometric parameters like drainage area, drainage density \& frequency, basin relief, slope etc. This quantitative investigation is important to characterize the watersheds. Javed et al. (2009) stated that prioritization of sub watersheds, linear morphometric parameters i.e. drainage density (Dd), stream frequency (Fs), length of overland flow (Lof), bifurcation ration $(\mathrm{Rb})$ and drainage texture have direct relationship, which means higher the value more is the erodibility and ranked accordingly. Whereas the other parameters i.e. circulatory ration $(\mathrm{Rc})$, elongation ratio $(\mathrm{Re})$, form factor (Rf), basin shape (Bs) and constant channel maintenance $(C)$ have inverse relationship i.e. means lower the value more is the erodibility and ranked accordingly. In this study, GIS/ RS approach used for morphometric analysis to prioritize sub-watershed for flood risk assessment in CKNP, which is one of the important aspect for NRM of the park.

\subsection{Study Area}

Central Karakoram National Park established in 1993, located in quailing mountains of mighty Karakoram Range. It covers $35^{\circ} \mathrm{N}$ to $36.5^{\circ} \mathrm{N}$ Latitude and $74^{\circ} \mathrm{E}$ to $77^{\circ} \mathrm{E}$ Longitude having mountains, glaciers, forest, villages and unkind rivers with population around 0.2 Million.

It is the largest source of fresh water used in Pakistan with largest glaciers in the world, including Siachen $(75 \mathrm{Km})$, Baltoro $(57 \mathrm{Km})$ and Hispur-Biafo $(122 \mathrm{Km})$. Based on 30 meter spatial resolutions Digital Elevation Model (DEM), fourteen watersheds delineated which cover the whole CKNP. In management prospective, this park is consisted of strictly conservation area and buffer zones (World Wild Life, Dec 2009). In the current study, three main watersheds Bagrote, Haramosh \& Rakaposhi (Figure 1) selected as the study area and this approach can be replicated for other watersheds of the park.

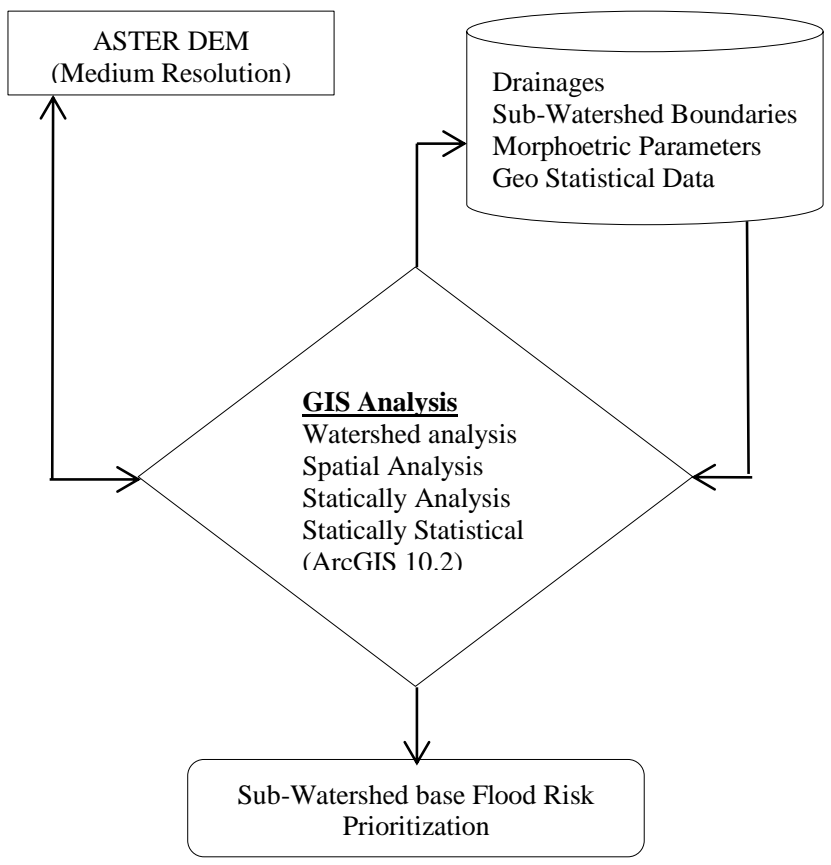

Figure 2: Research Framework 


\begin{tabular}{|c|c|c|c|}
\hline & $\begin{array}{l}\text { Morphometric } \\
\text { Parameters }\end{array}$ & Methods & Reference \\
\hline \multirow{5}{*}{ 点 } & Stream Order $(\mathrm{U})$ & Hierarchical order & Strahler, 1964 \\
\hline & Stream length $(\mathrm{Lu})$ & Length of stream & Horton, 1945 \\
\hline & Mean stream length (Lsm) & $\begin{array}{c}L s m=L u / N u \\
\text { where } \mathrm{Lu}=\text { Stream length of order ' } \mathrm{U} \text { ' } \\
\mathrm{Nu}=\text { Total number of stream segments of order ' } \mathrm{U} \text { ' }\end{array}$ & Horton, 1945 \\
\hline & Stream length ratio (RI) & $\begin{array}{c}R I=L u / L u-1 \\
\text { where } \mathrm{Lu}=\text { Total stream length of order ' } \mathrm{U} \text { ', } \\
\mathrm{Lu}-1=\text { Stream length of next lower order }\end{array}$ & Horton, 1945 \\
\hline & Bifurcation ratio $(\mathrm{Rb})$ & $\begin{array}{l}\qquad R b=N u / N u+1 \\
\begin{array}{l}\text { Where } \mathrm{Nu}=\text { Total number of stream segment of order ' } \mathrm{u} \text { '; Nu+1 } \\
=\text { Number of segment of next higher order }\end{array}\end{array}$ & Schumn, 1956 \\
\hline \multirow{3}{*}{ 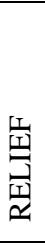 } & Basin relief $(\mathrm{Bh})$ & $\begin{array}{l}\text { Vertical distance between the lowest and highest point of } \\
\text { watershed }\end{array}$ & Schumn, 1956 \\
\hline & Relief ratio $(\mathrm{Rh})$ & $\begin{array}{c}R b=B h / L b \\
\text { where } \mathrm{Bh}=\text { Basin relief; } \mathrm{Lb}=\text { Basin length }\end{array}$ & Schumn, 1956 \\
\hline & Ruggedness number (Rn) & $\begin{array}{c}\qquad n=B h X D d \\
\text { Where, } \mathrm{Bh}=\text { Basin relief; } \mathrm{Dd}=\text { Drainage density }\end{array}$ & Schumn, 1956 \\
\hline \multirow{8}{*}{ 丕 } & Drainage density & $\begin{array}{c}R b=L / A \\
\text { where, } \mathrm{L}=\text { Total length of streams; } \mathrm{A}=\text { Area of watershed }\end{array}$ & Horton, 1945 \\
\hline & Stream frequency $(\mathrm{Fs})$ & $\begin{array}{c}\qquad R=N / A \\
\text { where, } \mathrm{L}=\text { Total length of streams; } \mathrm{A}=\text { Area of watershed }\end{array}$ & Horton, 1945 \\
\hline & Texture Ration $(\mathrm{T})$ & $\begin{array}{c}T=N 1 / P \\
\text { where, N1 Total number of first order streams; } \mathrm{P}=\text { Perimeter of } \\
\text { watershed }\end{array}$ & Horton, 1945 \\
\hline & Form factor (Rf) & $\begin{array}{c}\qquad T=A /(L b)^{2} \\
\text { where, } \mathrm{A}=\text { Area of watershed, } \mathrm{Lb}=\text { Basin length }\end{array}$ & Horton, 1932 \\
\hline & Circular ration $(\mathrm{Rc})$ & $\begin{array}{c}\qquad c=4 \pi A /(P)^{2} \\
\text { where, } \mathrm{A}=\text { Area of watershed, } \pi=3.14 \\
\mathrm{P}=\text { Perimeter of watershed }\end{array}$ & Miller, 1953 \\
\hline & Elongation ratio $(\mathrm{Re})$ & $\begin{array}{c}\quad \operatorname{Re}=2 \sqrt{(A / \pi)} / \mathrm{Lb} \\
\text { where } \mathrm{A}=\text { Area of watershed, } \pi=3.14 \\
\mathrm{Lb}=\text { Basin length }\end{array}$ & Schumn, 1956 \\
\hline & Length of overland flow (Lof) & $\begin{array}{c}L o f=1 / 2 D d \\
\text { where } \mathrm{Dd}=\text { Drainage density }\end{array}$ & Horton, 1945 \\
\hline & Constant Channel Maintenance (C) & $\begin{array}{c}C=1 / D d \\
\text { where } \mathrm{Dd}=\text { Drainage density }\end{array}$ & Horton, 1945 \\
\hline
\end{tabular}

Table 1: Methods of Calculating morphometric parameters Source (Rekha et al, 2011)

\section{DATA AND METHODOLOGY}

In this current study, drainage pattern and sub-watershed boundaries of the study area were derived initially using ASTER DEM provided by NASA with resolution of 30 meter. Using tools of spatial analyst including map algebra, zonal statistics and re-class of ArcGIS 10.2, geometric parameters of sub watershed drainage pattern were calculated.

The equations given in Table 1 used to calculate different morphometrical parameters of the extracted sub watersheds (Rakhna et al, 2011). These parameters also termed as erosion risk assessment parameters (Javed et al, 2009). The research framework used for morphometric analysis to prioritize the sub-watersheds of the study area has shown in Figure 2. In this frame work ASTER DEM data is used as primary input data, where ArcGIS spatial analysis tools are used as processing tools, and sub watershed based flood risk prioritization map is the general output.

The morphological parameters for the associated subwatersheds have been calculated in different units. Thus, through the standardization approach the score of units was reduced, which reflected the degree of risk factors for the selected parameters. All the standardized parameters were then added up into a single factor called Weighted Standardized Risk Factor (WSRF) as given in equation 6 (Elmoustafa M. A., 2012). 


$$
\begin{aligned}
& \text { Area Standardized Factor }(A S R F) \quad=\frac{A-A(\min )}{A(\max )-A(\min )} \\
& \text { Slope Standardized Factor }(S S R F)=\frac{S-S(\min )}{S(\max )-S(\min )} \\
& \text { Density Standardized Factor }(D d S R F)=\frac{D d-D d(\min )}{D d(\max )-D d(\min )} \\
& \text { Frequency Standardized Factor }(F S S R F)=\frac{F s-F s(\min )}{F s(\max )-F s(\min )} \\
& \text { Sandardized Factor }(T c S R F)=\frac{T c-t c(\min )}{T c(\max )-T c(\min )}
\end{aligned}
$$

$W S R F=\sum(W i * S R F i)$

Where $W_{i}$ is the weighted coefficient and taken as constant i.e. $(1 /$ (No of prapmeter $))$ as already defined by Elmoustafa (2012).

\section{RESULTS AND DISCUSSION}

Results pertaining to drainage pattern with stream order hierarchy calculated and mapped using GIS/RS tools as shown in figure 3. The stream order in study area varies from 1 to 6 as it is an initial step for morphometric analysis (Javed et al, 2009).

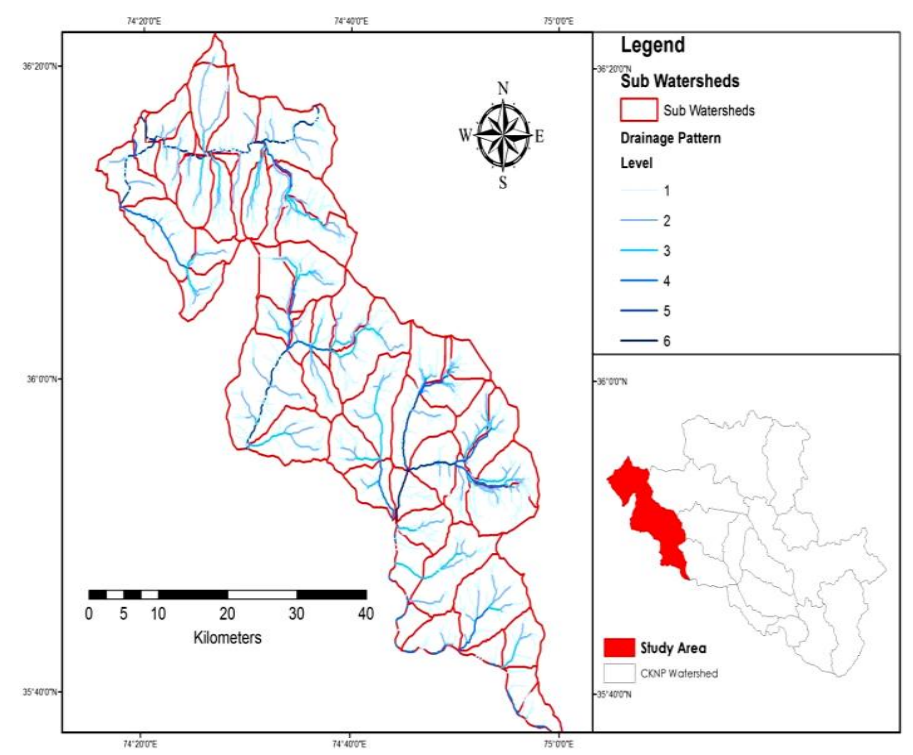

Figure 3: Drainage pattern of study area

Geometric values such as area and parameter calculated using ArcGIS 10.2. The elevation and slope factor of all subwatersheds extracted from ASTER DEM geospatial dataset using spatial analyst tool (Figure 4).

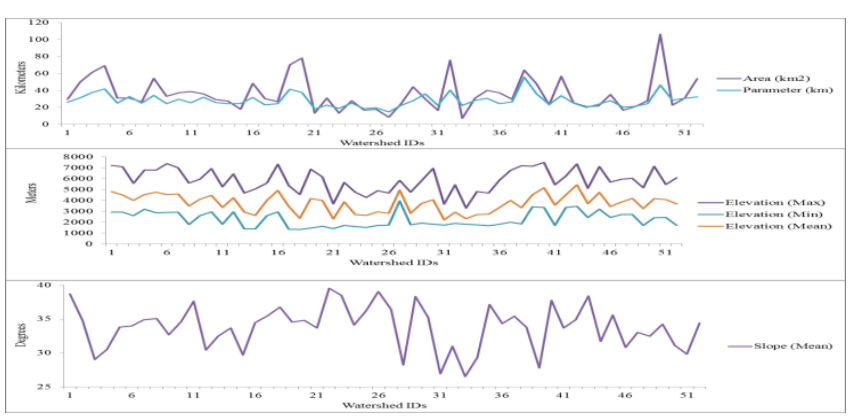

Figure 3: Goe-Features of the study Area
Using the values of the said geometric parameters and equations cited in table 1 , other morphometric parameters calculated which were further standardized using the equations numbered in methodology section. Standardized parameters and Weighted Standardized Risk Factor (WSRF) are further classified into five categories in order to prioritize the subwatershed for the flush flood risk. The values of WSRF are mapper in Figure 5.

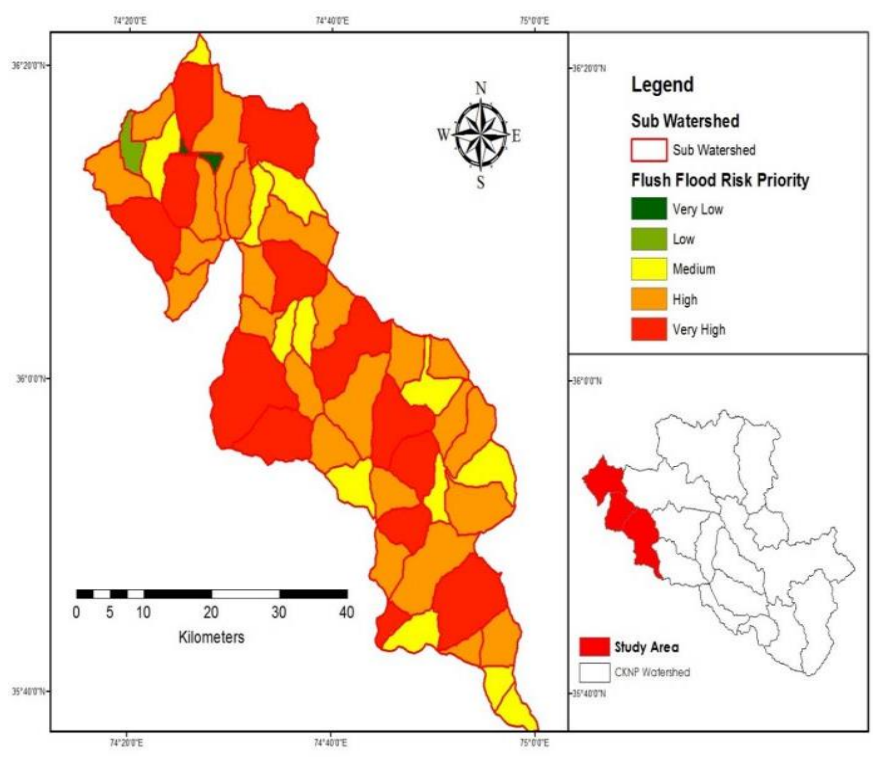

Figure 5: Flush flood risk priority classification

The resulted WSRF correlated with some selected parameters as shown in Table 2, where it depicts that drainage density has great correlation of floods followed by time of concentration.

\begin{tabular}{|l|l|l|l|l|l|l|l|}
\cline { 2 - 8 } \multicolumn{1}{c|}{} & $\mathrm{A}$ & $\mathrm{m}$ & $\mathrm{Dd}$ & $\mathrm{fc}$ & $\mathrm{tc}$ & Lof & WSRF \\
\hline $\mathrm{A}$ & 1.00 & & & & & & 0.50 \\
\hline $\mathrm{m}$ & & 1.00 & & & & & 0.41 \\
\hline $\mathrm{Dd}$ & & & 1.00 & & & & 0.70 \\
\hline $\mathrm{fc}$ & & & & 1.00 & & & 0.35 \\
\hline tc & & & & & 1.00 & & 0.66 \\
\hline Lof & & & & & & 1.00 & 0.52 \\
\hline WSRF & & & & & & & 1.00 \\
\hline
\end{tabular}

Table 2: Correlation A (Area), m (Slope), Dd (Density), fc (Frequency), tc (Time of concentration), Lof (Length of overflow)

\section{CONCLUSION}

Morphometric parameters are important in assessing the risk of flush floods especially where use GIS/ RS technology is one of the emerging techniques. The results of current endeavour indicated that there was a positive co- relation between drainage area, number of drains and time of concentration. Prioritization of sub watershed using the WSRF gives a clear understanding of the flood prone areas of the region. These outcomes in current research will be helpful for researchers, students, and policy makers in adequate natural resource management of CKNP which is one of the important areas of the world for climate change assessment in prospect of flood risk mitigation. 


\section{REFERENCES}

Bagyaraj, M., Gurugnanam, B., \& Nagar, A. (2011). Significance of morphometry studies, soil characteristics, erosion phenomena and landform processes using remote sensing and GIS for Kodaikanal Hills, a global biodiversity hotpot in Western Ghats, Dindigu District, Tamil Nadu, South India. Research Journal of Environmental and Earth Sciences, 3(3), 221-233.

Bapalu, G. V., \& Sinha, R. (2005). GIS in flood hazard mapping: A case study of Kosi River Basin, India. GIS Development Weekly, pp. 1-3.

Bhatt, S., \& Ahmed, S. A. (2014). Morphometric analysis to determine floods in the Upper Krishna basin using Cartosat DEM. Geocarto International , 29(8), 878-894.

El Maghraby, M., Masoud, M., \& Niyazi, B. (2014). Assessment of Surface Runoff in Arid, Data Scarce Regions; An Approach Applied in Wadi Al Hamd, Al Madinal al Munawarah, Saudi Arabia. Life Science Journal , 11(4).

El-Behiry, M. G., Shedid, A., \& Abu-Khadra, A. (2006). Integrated GIS and remote sensing for runoff hazard analysis in AIn Sukhna industrail area, Egypt. Earth Sciences , 19-41.

Elmoustafa, A. M., \& Mona , M. M. (2013). lash Flood Risk Assessment Using Morphological Parameters in Sinai Peninsula. Open Journal of Modern Hydrology .

Elmoustafa, M. A. (2012). Weighted normalized risk factor for floods risk assessment. Ain Shams Engineering Journal , 327332.

FloodList. (2017). Asia. Retrieved September 09, 2017, from Reporting floods and flooding news since 2008: http://floodlist.com/asia/pakistan-gilgit-baltistan-august-2017

Javed, A., Ahmad, R., \& Khanday, M. Y. (2009). Prioritization of Sub-watersheds based on Morphometric and Land Use Analysis using Remote Sensing and GIS Techniques. Jounal of Idian , 261-274.

Omran, A., Schroder, D., EL, R. A., \& Geriesh, M. (2011). Flood Hazard Assessment in Wadi Dahab, Egypt Based on Basin Morphometry Using GIS Techniques. GI_Forum Program Committee.

Patton, C. P., \& Baker, R. V. (1976). Morphometry and Floods in Small Drainage Basins Subject to Diverse Hydrogeomorphic Controls. Water Resources Research , 12.

Patton, P. C. (1988). Drainage basin morphometry and floods. In Flood Geomorphology (pp. 51-64). New York: John Wiley \& Sons

Pisal, P. A., Yadav, A. S., \& Chavan, A. (2013). Morphometric Analysis Of Bhogavati River Basin, Kolhapur District, Maharashtra, India. Journal of Mechanical and Civil Engineering (, 01-08.

Strahler, A. N. (1957). Quantitative Analysis of Watershed Geomorphologuy. Transaction American Geophysical Union , Vol 38, No 6.
Subyani, A. M., \& Al-Ahmadi, F. S. (2011). RAINFALLRUNOFF MODELING IN THE AL-MADINAH AREA OF WESTERN SAUDI ARABIA. Journal of Environmental Hydrology .

Sujata, B., Sudhakar, S., \& V R, D. (1999). Prioritisation of sub watersher based on morphomatric analysis of drainage basin; A remote sensing and GIS approach. Journal of the Indian Soceity of Remote Sensing, Vol. 27 No. 3.

The Express Tribune Blogs. (2016, Feb 15). Retrieved from The Express Tribune:

http://tribune.com.pk/story/933507/over-a-million-peopleaffected-by-floods-in-pakistan-ndma/

Waikar, M. L., \& Nilawar, A. P. (2014). Morphometric Analysis of a Drainage Basin Using Geographical Information System: A Case study. International Journal of Multidisciplinary and Current Research , 2.

World Wild Life. (Dec 2009). Land cover mapping of Central Karakoram National Park. GIS Laboratories.

Youssef, A. M., Pradhan, B., \& Hassan, A. M. (2011). Flash flood risk estimation along the St. Katherine road, southern Sinai, Egypt using GIS based morphometry and satellite imagery. Environmental Earth Sciences , 62(3), 611-623. 